\title{
Effect of Automated Teller Machines Usage on Operational Performance of Commercial Banks in Nakuru County, Kenya
}

\author{
Hussein Mohamed Abdullai, Richard Bitange Nyaoga \\ Faculty of Commerce, Department of Accounting, Finance and Management Science, Egerton University, Nakuru, Kenya \\ Email address: \\ hussumoha@yahoo.com (H. M. Abdullai),rnyaoga@yahoo.com (R. B. Nyaoga)

\section{To cite this article:} \\ Hussein Mohamed Abdullai, Richard Bitange Nyaoga. Effect of Automated Teller Machines Usage on Operational Performance of \\ Commercial Banks in Nakuru County, Kenya. International Journal of Economics, Finance and Management Sciences. \\ Vol. 5, No. 3, 2017, pp. 162-167. doi: 10.11648/j.ijefm.20170503.14
}

Received: May 2, 2017; Accepted: May 13, 2017; Published: May 23, 2017

\begin{abstract}
The aim of this paper was to determine the effect of Automated Teller Machines usage on operational performance of commercial banks in Nakuru County, Kenya. The study was guided by the research objective: to establish the effect of automated teller machines (ATMs) usage on operational performance of commercial banks in Nakuru County, Kenya.The study employed the following theories namely: Diffusion of Innovation and The Theory of Reasoned Action. The study adopted a correlational-cross-sectional research design. The study population comprised 56 employees of the 28 commercial banks. There are 31 commercial banks branches in Nakuru County, Kenya with Kenya Commercial Bank, Co-operative Bank and Equity bank having 3,2 and 3 branches respectively which makes a total of 31 commercial banks out of which the researcher, through a simple random sampling, chose 28. Data was collected using structured questionnaires. A pilot study was conducted in Eldoret Town, Uashin Gishu County to determine validity of the research instruments where Cronbach's alpha coefficient was employed. For the purpose of determining the effect of ATMs usage on operational performance, correlation and regression analysis were carried out. The study established that ATM usage has a positive significant relationship with operational performance. The study recommends that managements of commercial banks should highly invest in ATMs as it positively influences operational performance. The study suggests that further studies should be conducted to relate ATMs with other variables like quality and flexibility.
\end{abstract}

Keywords: Automated Teller Machines, Operational Performance, Commercial Banks

\section{Introduction}

In today's contemporary business environment, the need for Automated Teller Machines cannot be overemphasized. The banking industry adopted the ATM concept for reducing costs and providing better services for the customers. The first ATM was installed in the early 1967 by Barclays bank in London, UK. The banks started installing ATM machines in the bank buildings first where a cash dispensing machine was not linked to the account directly. With the spread of Internet connectivity, the ATM machines have become a part of the urban landscape and available at parks, shopping malls or airports with many more services on offer than just cash dispensing [1]. There are many different ways of measuring operational performance. However, the most predominant approach in the literature is to use cost, quality, delivery, speed, reliability and flexibility as the basic dimensions of operational performance [3].

\subsection{Statement of the Problem}

Commercial banks have automated their services by use of Automated Teller Machines (ATMs). The aim has been to schedule employees' duties with ease, reduce the building up of queues and increase employees' efficiency. Other reasons for adopting ATMs include; reduction of customer service delivery time, improvement of quality of service, bringing services closer to customers and cutting on cost of operations. The overall aim is to achieve the highest possible 
level of profits. While Commercial banks have adopted SSTs to make services conveniently available to customers. [13] argue that there are many customers still transacting with tellers within the doors of the banks, and customers are found in queues every time in banking halls and ATMs. Similarly, these systems remained largely unnoticed by the customers and certainly are seriously underused. According to [21], the queues develop due to system downtime and there is inefficiency in the operations since all the operations cannot run as required. Most studies done on ATMs concentrated mainly on customers experience, for example, [10] did a study on perceived service quality and satisfaction of selfservice technology. [17] argued that there is a high degree of customer complaints with ATMs downtime, cash out, high charges and sometimes, poor service recovery efforts when customers have problems. Past studies have focused on other areas of ATMs and not specifically ATMs and operational performance therefore not providing the effect of ATMs usage on operational performance. Organizations therefore, adopt ATMs without certainty on the expected outcome in terms of operational performance. It is therefore; evident that literature gap exists on the exact effect of ATMs usage on operational performance. Hence this study seeks to establish the effect of ATMs usage on operational performance of commercial banks in Nakuru County, Kenya.

\subsection{Objective of the Study}

To establish the effect of Automated Teller Machines usage on operational performance of commercial banks in Nakuru County, Kenya.

\subsection{Research Hypotheses}

Automated Teller Machines (ATMs) usage has no effect on operational performance of commercial banks in Nakuru County, Kenya.

\subsection{Conceptual Framework}

In this framework, Automated Teller Machine usage is independent variable and operational performance is dependent variable. The independent variable, Automated Teller Machines usage is operationalized through: cash deposit, cash withdrawal and balance inquiry while the dependent variable is operationalized through: cost of operations, reliability of service and speed of service. The moderating variable includes board management decisions, capital adequacy and macroeconomic factors.

As shown in Figure 1 above, there exists a relationship between independent and dependent variables in this study. However these variables are affected by contextual factors such as board management decisions, capital adequacy and macroeconomic factors.

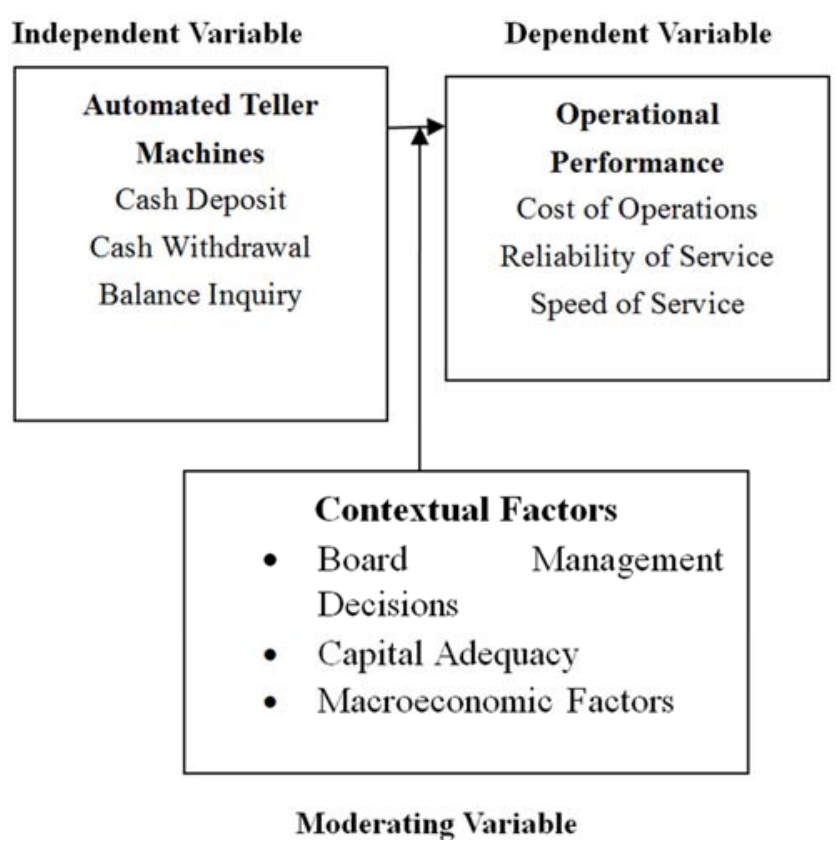

Figure 1. Relationship between Automated Teller Machines Usage, Contextual Factors and Operational Performance of Commercial Banks.

\section{Literature Review}

\subsection{Diffusion of Innovation}

This theory was developed by Everett M. Rogers in 1983. Diffusion of innovation is a theory of how, why, and at what rate new ideas and technology spread through cultures, performing at the individual and firm level. The theory finds innovations as being transmitted through certain channels over time and within particular social systems. Individuals are seen as possessing different degrees of willingness to adopt innovations, and thus it is generally observed that the portion of the population adopting an innovation is approximately normally distributed over time [16]. According to [16], diffusion is the process by which an innovation is communicated through certain channels over time among the members of a social system.

The researcher further argued that it is a special type of communication because messages are concerned with new ideas, the more compatible the technology will be to users the less a change of behavior is required, therefore, allowing for faster adoption. Trialability is the degree that the innovation can be tested and experimented before its inclusion. The complexity (its ease of use) of technology will also impact on adoption. If the use of technology requires considerable learning it is less likely that users will persevere with it and observability, is whereby the innovation use and effects must be visible by others. In the context of this study, this theory suggests that the degree of bankers adopting new technology depends on the willingness of the individuals and the more the technology is compatible with the needs of the bankers, the faster the adoption. 


\subsection{Theory of Reasoned Action}

This theory was developed by Martin Fishbein and Icek Ajzen in 1963.Theory of Reasoned Action proposes that an individual's behavior is determined by his/her intention to perform the behavior and that this intention is, in turn, a function of his/her attitude toward the behavior and his/her subjective norm. The best predictor of behavior is intention that the individual has. This intention is determined by three things: their attitude toward the specific behavior, their subjective norms and their perceived behavioral control. The theory of planned behavior holds that only specific attitudes toward the behavior in question can be expected to predict that behavior. In the context of this study, this theory puts forth that intention of the bankers and the management affect their behavior towards the technology to be adopted [12].

\subsection{Empirical Review}

\subsubsection{Automated Teller Machines (ATMs)}

According to [18], Automated Teller Machines (ATMs) is a computerized telecommunications device that provides the customers of a financial institution with access to financial transactions in a public space without the intervention of a human clerk or a bank teller. Such transactions are done by inserting a personal "bank card" into the machine and the client/customer accessing his/her bank account using a personal identification number (PIN) which is inserted into the machine before the transaction can continue.

According to [10], over the last few decades, the automated teller machine as part of self-service technology (SSTs) has emerged as a major channel for routing banking services to customers. Reasons for the introduction of ATMs in retail banking include lower labour cost, efficiency, greater consumer involvement, standardization of service delivery, customer satisfaction and loyalty. [6] contends that less than the benefits, the deployment of ATMs terminals have averagely improved the performance of Nigerian banks because of the alarming rate of ATM fraud. According to [10], convenience, reliability, ease of use, privacy, security, responsiveness and fulfillment were found to be the major dimensions of ATMs service quality. [7] argued that card issues, reliability, and location are the most important students' service quality evaluation diemensions of ATMs in Uganda. The study further recommends that managers should consider the identified diemensions when designing an ATM network to encourage usage of ATM facilities and decongest their banks.

\subsubsection{Automated Teller Machines Usage and Operational Performance}

According to [9], operational performance is a process of assessing progress toward achieving predetermined goals, including information on the efficiency with which resources are transformed into outputs both goods and services. The quality of those outputs is how well they are delivered to clients and the extent to which clients are satisfied and outcomes is the results of a program activity compared to its intended purpose.

According to [19], there are five basic "operational performance objectives" that are considered to apply to all types of operations. These all-pervasive operational performance objectives are quality, speed, dependability, flexibility and cost and they provide the key incentive for operations management tools and techniques, such as kanbans, Statistical Process Control (SPC), Enterprise Resource Planning (ERP), and just-in-time (JIT), all of which are directed on doing things better, faster, more efficiently, and more cheaply.

According to [8], operations performance factors for manufacturing firms are well established in the operations literature, which identifies cost, flexibility, quality, dependability, and speed as critical manufacturing competitive priorities. [8] argue that operations performance of service delivery comprises three critical performance factors (quality, dependability, and speed) that are usually present in a service delivery system. Consistent quality, dependability of delivery, and prompt delivery (speed) are critical operations performance factors in service delivery systems. [15] have also considered four criteria to measure the operational performance. These criteria are quick delivery compared to the major competitor, unit cost of product relative to competitors, overall productivity and overall customer satisfaction. These measures are derived from several criteria, which have been conceptualized and used in previous empirical studies of lean manufacturing and supply chain management. According to [20], supply chains, human resources, and design of production systems have remarkable positive effects on the flexibility and flow measures while quality is only related to the design of the production system. According to [2], many banks in Nigeria have over the years streamlined their organizations, tailored their products and services delivery and automated their operations to enhance their performances and capture the market. As the struggle to enhance performance by the deposit money banks, the focus is moving to the complete automation of all their operations and services. The system or industry is highly competitive and it is expected to motivate new players of local and global scope to enter the market. As the competitive terrain becomes more challenging, banks need to maintain their competitive edge, and to do this, they have to adopt new innovations.

\section{Research Methodology}

\subsection{Research Design}

This study adopted a correlational-cross-sectional research design. According to [22], cross-sectional research design is a research approach in which the researchers investigate the state of affairs in a population at a certain point in time. Very often, the elements in the sample survey are selected at random to make inference about the population as a whole. 
The purpose of a correlational study is to establish whether two or more variables are related.

\subsection{Target Population}

The target population of this study comprised of the commercial banks in Nakuru County, Kenya while the respondents were the operations and IT managers of the commercial banks in Nakuru County, Kenya. There are 56 operations and IT managers in all the commercial banks branches. There are 31 commercial banks branches in Nakuru County (Nakuru County Government, 2016) with Kenya Commercial Bank, Co-operative Bank and Equity bank having 3,2 and 3 branches respectively which makes a total of 31 commercial banks out of which the researcher, through a simple random sampling, chose 28 .

\subsection{Data Collection}

Primary data was collected regarding the effect of automated teller machines usage and operational performance. Data was collected using structured questionnaires. The questionnaires were administered to the respondents through drop and pick method. The drop and pick approach is considered an appropriate method for the study because it gives the respondents time to fill the questionnaire and allows the researcher an opportunity to review the questionnaires before picking them to ensure completeness of responses. Questionnaires are preferred because of their simplicity and low cost associated [14].

\subsection{Data Analysis and Presentation}

Data was collected, coded and analyzed through SPSS (Statistical Package for Social Sciences) version 20. Pearson Product-Moment correlation was used to test the hypothesis that ATMs usage has no effect on operational performance. ANOVA test was used to test the significance of the model. Values more than 0.05 indicated statistically insignificant relationships while value less than 0.05 indicated statistically significant relationships. Hypothesis was tested at 5\% significance level. The following general multiple regression model below was used in the study.

$$
Y=\beta_{0}+\beta_{1} x_{1}+\varepsilon
$$

$\mathrm{Y}=$ Operational performance

$\beta_{0}=$ constant

$\beta_{1}=$ Regression Coefficients

$\mathrm{X}_{1}=\mathrm{ATM}$

$\mathcal{E}=$ Error Term

\section{Findings and Recommendations}

\subsection{Correlation Analysis}

Correlational Analysis between Automated Teller Machines Usage and Operational Performance

A correlation analysis was conducted to establish the effect of ATMs usage on operational performance. The results of the analysis were as presented in table 1 below

Table 1. Correlation Analysis between Automated Teller Machines Usage and Operational Performance.

\begin{tabular}{llll}
\hline Variables & & ATMs Usage & Operational Performance \\
\hline & Pearson Correlation & 1 & \\
Automated Teller Machines usage & Sig. (2-tailed) & & 1 \\
Operational Performance & $\mathrm{N}$ & $.545^{* *}$ & 26 \\
\hline
\end{tabular}

\subsection{Hypothesis Testing}

Relationship between Automated Teller Machines Usage and Operational Performance.

The study sought to establish whether Automated Teller Machines usage has a significant relationship with operational performance. The results in Table 1 above showed that there is significant positive correlation between automated teller machines usage and operational performance $(r=0.545, \mathrm{p}<0.05)$. The hypothesis, that ATMs usage has no effect on operational performance of commercial banks was thus rejected. Therefore, it was concluded that ATM usage is highly related to operational performance. This study is consistent with the findings of [6] who argued that Automated Teller Machines contribute to the effectiveness of banking sector. He further argued that Automated Teller Machine stimulate banking industry growth. This is expressed in the number of customers using the ATMs.

Effect of ATMs Usage on Operational Performance

A multiple regression analysis was conducted to establish the effect of ATMs usage on operational performance. The results were as shown in table 2 below

Table 2. Multiple Regression Results for Effect of ATMs Usage on Operational Performance.

\begin{tabular}{lllll}
\hline Model & R & R Square & Adjusted R Square & Std. Error of the Estimate \\
\hline 1 & $.656^{\mathrm{a}}$ & .430 & .422 & .48841 \\
\hline
\end{tabular}

a. Predictors: (Constant), Automated Teller Machines Usage

The model summary of the regression analysis in Table 2 above shows that automated teller machines usage accounted for $43 \%$ of the variance in operational performance of the commercial banks in Nakuru County, Kenya (R Square $=0.43)$. This explains that $57 \%$ of the variance in operational performance was explained by variables not in the study. 
Table 3. Significance of the Effect of ATMs Usage on Operational Performance.

\begin{tabular}{lllllll}
\hline \multicolumn{7}{c}{ ANOVA $^{\mathbf{a}}$} \\
\hline Model & & Sum of Squares & Df & Mean Square & F & Sig. \\
\hline & Regression & 38.018 & 3 & 12.673 & 53.126 & $.000^{\mathrm{b}}$ \\
& Residual & 50.332 & 23 & .239 & & \\
& Total & 88.351 & 26 & & & \\
\hline
\end{tabular}

a. Dependent Variable: Operational Performance

b. Predictors: (Constant), Automated Teller Machines Usage

From Table 3 above, the ANOVA shows significance of the effect of ATMs usage on operational performance. The significance value $(p)$ of 0.000 gives the test on the entire model. Since the value of $(F=53.126, p<0.05)$, the model was significant.

Table 4. Table of Coefficient.

\begin{tabular}{llllllll}
\hline \multirow{2}{*}{ Model } & \multicolumn{2}{c}{ Unstandardized Coefficients } & Standardized Coefficients & \multirow{2}{*}{ T } & & \multirow{2}{*}{ Sig. } & \multicolumn{2}{l}{ Collinearity Statistics } \\
\cline { 2 - 4 } & B & Std. Error & Beta & & & Tolerance & VIF \\
\hline (Constant) & 1.761 & .179 & & 9.855 & .000 & \\
Automated Teller Machines Usage & .073 & .080 & .085 & .922 & .000 & .315 & 3.171 \\
\hline
\end{tabular}

a. Dependent Variable: Operational Performance

Table 4 above shows the significance (p) values for the independent variable (ATMs). If $\mathrm{p}<0.05$, the conclusion is that the independent variable is a predictor of the dependent variable. In testing the effect of ATMs usage on operational performance, significance value of $(p)=0.000$ which is less than 0.05 shows that automated teller machines usage has statistical significant relationship with operational performance. The standardized coefficient shows that the effect of ATMs usage on operational performance is significant and positive $(\beta=0.085, \mathrm{t}=0.922, \mathrm{p}<0.05)$. The Unstandardized coefficient shows that for every increase in ATMs usage, a 0.073 increase in operational performance is predicted. Multicollinearity test was conducted to determine the correlation of the explanatory variable. Multicollinearity occurs when two or more predictors in the model are correlated and provide redundant information about the response [4]. The diagnostics variance inflation factor (VIF) and tolerance were used to test multicollinearity of the independent variable. According to [11] a tolerance value less than 0.1 or VIF greater than ten (10) roughly indicates significant multicollinearity. The results of this study indicate that Tolerance values were greater than 0.1 and VIF values were much lower than the recommended cut-off of 10 [4], thus suggesting the absence of multicollinearity in the data (Automated Teller Machines usage $=3.171$ ). Therefore, the equation for the regression model can be given by:

$$
Y=1.761+0.073 x_{1}
$$

\section{Conclusions}

The objective of the study was to establish the effect of automated teller machines usage on operational performance of commercial banks in Nakuru County, Kenya. The study concluded that ATMs usage is highly related with operational performance. This shows that the adoption of automated teller machines has a positive influence on operational performance. This correlates the study by [5] who concluded that ATM cards significantly influenced the operational efficiency of commercial banks in Kenya.

\section{Recommendations of the Study}

The aim of this study was to establish the effect of ATMs usage on operational performance of commercial banks in Nakuru County, Kenya. The findings of this study have various implications for management of commercial banks and management policy and practice as explained below.

\subsection{Recommendations for Management Policy and Practice}

This study has implications for management and practice. First, the study established that there is a positive significant relationship between ATMs usage and Operational performance. Therefore, ATMs usage has significant influence on operational performance. Thus to create a competitive edge and improve operational performance, the study therefore recommends that management of commercial banks and other financial institutions invest more in this technology as it contributes immensely to their operational performance. Commercial bank managers and government should properly adopt strategy that will encourage businessmen and general public in using automated teller machine which will improve effectiveness and efficiency of the banking sector. Further recommendation of this study is that ATMs should be put in different locations easily accessible by customers, so that quick service and convenience is maintained hence improving bank operations. At the same time constantly serviced in order to provide 
reliability of the services.

\subsection{Recommendations for Further Research}

More academic research should be conducted to establish the effect of ATMs usage on operational performance in other sectors other than banking as the study focused only on commercial banks in order to establish whether ATMs usage does affect their operational performance. Further research can be carried out by including additional variables like quality and flexibility. The study can also be replicated in other countries and this will enhance further understanding of the relationship between ATMs usage and operational performance.

\section{References}

[1] Abdelaziz, S. G., Hegazy, A. A., \& Elabbassy, A. (2010). Study of Airport Self-Service Technology within Experimental Research of Check-in Techniques: Case Study and Concept. International Journal of Computer Science, 7(3), 17-26.

[2] Abdullahi, Y. (2012). Services Automation And Performance : Evidence From Deposit Money Banks in Nigeria. International Journal of Advanced Research in Management and Social Sciences, 1(2), 47-58.

[3] Agboola, A. A. (2003). Information Technology, Bank Automation, and Attitude of Workers in Nigerian Banks. Journal of Social Sciences, 7(3), 215-222.

[4] Bitange, R., Wang, M., \& Obara, P. (2015). Testing the Relationship between Constraints Management and Capacity Utilization of Tea Processing Firms : Evidence from Kenya. Future Business Journal, 1, 35-50. http://doi.org/10.1016/j.fbj.2015.10.001

[5] Jattani, G. (2014). Effect of Technology Adoption on Operational Efficiency of Commercial Banks in Kenya.

[6] Jegede, C. A. (2014). Effects of Automated Teller Machine on the Performance of Nigerian Banks. American Journal of Applied Mathematics and Statistics, 2(1), 40-46. http://doi.org/10.12691/ajams-2-1-7

[7] Katono, I. W. (2011). Student Evaluation of e-Service Quality Criteria in Uganda: The Case of Automatic Teller Machines. International Journal of Emerging Markets, 6(3), 200-216. http://doi.org/10.1108/17468801111144049

[8] Kumar, V., Batista, L., \& Maull, R. (2011). The Impact of Operations Performance on Customer Loyalty. Service Science, 3(2), 158-171.

[9] Kyuska, J. M. (2015). Effect of Logistics Outsourcing on The Operational Performance of Shipping Industry in Kenya. University of Nairobi.
[10] Narteh, B. (2015). Perceived Service Quality and Satisfaction of Self-Service Technology: The Case of Automated Teller Machines. International Journal of Quality \& Reliability Management, 32(4), 361-380.

[11] O'Brien, R. M. (2007). A Caution Regarding Rules of Thumb for Variance Inflation Factors. Quality \& Quantity, 41, 673690. http://doi.org/10.1007/s11135-006-9018-6

[12] Oduor, R. A. (2012). Adoption of The Automated Bill Enquiry And Bill Payment System by Customers of The Kenya Power and Lighting Company in Kisumu. University of Nairobi.

[13] Olatokun, W. M., \& Igbinedion, L. J. (2009). The Adoption of Automatic Teller Machines in Nigeria: An Application of the Theory of Diffusion of Innovation Louisa Joyce Igbinedion. Issues in Informing Science and Information Technology, 6, 373-393.

[14] Oruma, W. B. (2014). Factors Influencing Implementation of Total Quality Management in Construction Companies in Kenya : A Case of Nakuru County. University of Nairobi.

[15] Rahman, S., Laosirihongthong, T., \& Sohal, A. S. (2010). Impact of Lean Strategy on Operational Performance: A Study of Thai Manufacturing Companies. Journal of Manufacturing Technology Management, 21(7), 839-852. http://doi.org/10.1108/17410381011077946

[16] Rogers, E. M. (1983). Diffusion of Innovations (Third Edit). London: The Free Press.

[17] Sanda, M.-A., \& Arhin, E. (2011). Using ATMs as Workload Relievers for Ghanaian Bank Tellers: The Customer Behavioral Challenge. Journal of Economics and Behavioral Studies, 3(1), 13-21.

[18] Sewpersad, S. (2010). An Investigation of The Bombing of Automated Teller Machines (ATMs) With Intent To Steal Cash Contents : Case Study From Gautng. University of South Africa.

[19] Staughton, R., \& Johnston, R. (2005). Operational Performance Gaps in Business Relationships. International Journal of Operations \& Production Management,25(4),320332. http://doi.org/10.1108/01443570510585525

[20] Taj, S., \& Morosan, C. (2011). The Impact of Lean Operations on The Chinese Manufacturing Performance. Journal of Manufacturing Technology Management, 22(2), 223-240. http://doi.org/10.1108/17410381111102234

[21] Wang, Y.-S., Wang, Y.-M., Lin, H., \& Tang, T.-I. (2003).Determinants of User Acceptance of Internet Banking : An Empirical Study. International Journal of Service Industry Management, 14(5), 501-519. http://doi.org/10.1108/09564230310500192

[22] Zheng, M. (2015). Conceptualization of Cross-Sectional Mixed Methods Studies in Health Science: A Methodological Review. International Journal of Quantitative and Qualitative Research Methods, 3(2), 66-87. 